\title{
Depression and cigarette smoking independently relate to reduced health-related quality of life among Canadians living with hepatitis $\mathrm{C}$
}

\author{
Louise Balfour $\mathrm{PhD}^{1,2,3}$, Curtis Cooper $\mathrm{MD}^{1,2,3}$, John Kowal PhD ${ }^{1,2}$, Giorgio A Tasca PhD ${ }^{2,3,4}$, \\ Amy Silverman $\mathrm{PhD}^{1}$, Marie Kane $\mathrm{RN}^{1}$, Gary Garber $\mathrm{MD}^{1,2,3}$
}

\begin{abstract}
L Balfour, C Cooper, J Kowal, et al. Depression and cigarette smoking independently relate to reduced health-related quality of life among Canadians living with hepatitis C. Can J Gastroenterol $2006 ; 20(2): 81-86$.
\end{abstract}

BACKGROUND: Many people living with chronic viral hepatitis $\mathrm{C}$ (HCV) report reduced health-related quality of life. The relative contribution of behavioural, psychosocial and HCV disease factors to reduction in HCV health-related quality of life is not well understood. The objectives of the present study were to compare standardized health-related quality of life scores between Canadian HCV patients and age-matched Canadian and American norms, and to examine the relative contribution of biopsychosocial variables (ie, cigarette smoking, alcohol intake and depression) to health-related quality of life scores among Canadian HCV patients.

METHODS: HCV RNA-positive patients were recruited during their first visit to the Ottawa Hospital Viral Hepatitis Clinic (Ottawa, Ontario). A questionnaire assessing health behaviours, health-related quality of life and depressed mood was completed. Data on liver studies, liver biopsy findings and HIV serostatus were also collected.

RESULTS: A total of 123 participants ( $71 \%$ men) ranging from 20 to 67 years of age were evaluated. All had compensated liver function. Patients reported significantly lower health-related quality of life compared with age-matched Canadian and American normative samples. In a series of hierarchical multiple regression models, depression and smoking were independently related to compromised health-related quality of life scores, even after controlling for sociodemographic variables and health behaviours.

DISCUSSION: These results highlight the value of adopting a biopsychosocial model of HCV care. Depressed mood and smoking behaviour should be evaluated in HCV patients. Empirically validated psychological and pharmacological treatments for depression and smoking cessation may improve health-related quality of life in HCV infected patients.

Key Words: Cigarette smoking; Depression; Health-related quality of life; Hepatitis C
La dépression et le tabagisme sont séparément associés à une diminution de la qualité de vie reliée à la santé chez les Canadiens atteints d'hépatite $\mathrm{C}$

HISTORIQUE : Bien des gens atteints du virus de l'hépatite C (VHC) chronique font état d'une diminution de la qualité de vie reliée à la santé. On comprend mal la contribution relative de facteurs comportementaux, psychosociaux et reliés au VHC à la diminution de la qualité de vie reliée au VHC. La présente étude visait à comparer des indices standardisés de qualité de vie reliée à la santé de patients canadiens atteints du VHC aux normes canadiennes et américaines appariées selon l'âge et à examiner la contribution relative de variables psychosociales (p. ex., tabagisme, consommation d'alcool et dépression) aux indices de qualité de vie reliés à la santé chez des patients canadiens atteints du VHC.

MÉTHODOLOGIE : Des patients dont l'ARN était positif au VHC ont été recrutés à leur première consultation à la clinique d'hépatite virale de l'Hôpital d'Ottawa (Ottawa, Ontario). Un questionnaire visant à évaluer les comportements de santé, la qualité de vie reliée à la santé et les humeurs dépressives a été rempli. Des données sur les bilans hépatiques, les résultats des biopsies du foie et l'état sérologique du VIH ont également été colligées.

RÉSULTATS : Au total, 123 participants (71\% d'hommes) de 20 à 67 ans ont été évalués. Tous les patients présentaient une fonction hépatique compensée. Les patients faisaient état d'une qualité de vie reliée à la santé considérablement plus faible que celle des échantillons canadiens et américains normatifs appariés selon l'âge. Dans une série de modèles hiérarchiques de régression multiple, la dépression et le tabagisme étaient séparément associés à une diminution des indices de qualité de vie reliée à la santé, même après un contrôle tenant compte des variables sociodémographiques et des comportements reliés à la santé.

EXPOSÉ : Ces résultats soulignent l'intérêt d'adopter un modèle biopsychosocial de soins du VHC. Une humeur dépressive et le tabagisme devraient être évalués chez les patients atteints du VHC. Des traitements psychologiques et pharmacologiques de la dépression et de la désaccoutumance au tabac, validés de manière empirique, peuvent améliorer la qualité de vie reliée à la santé des patients infectés par le VHC.
Patients chronically infected with hepatitis $\mathrm{C}$ virus (HCV)
often report symptoms including fatigue, nausea, anorexia,
muscle aches, joint pain, irritability, headaches and problems
with memory/concentration, which compromise their health-
related quality of life $(1,2)$. These impairments in health-related
quality of life span the entire HCV disease spectrum, from mild
to more advanced liver disease $(1,3)$. These reductions in health-related quality of life affect physical, social and occupational functioning and have important clinical and social relevance.

Cigarette smoking has many known negative health consequences (4) and has been consistently associated with reduced health-related quality of life $(4,5)$. Almost all tissues and systems in the body are negatively affected by cigarette smoking.

\footnotetext{
${ }^{1}$ The Ottawa Hospital Division of Infectious Diseases Viral Hepatitis Program; ${ }^{2}$ University of Ottawa; ${ }^{3}$ Ottawa Health Research Institute;

${ }^{4}$ Carleton University, Ottawa, Ontario

Correspondence and reprints: Dr Louise Balfour, Room 7300-501 Smyth Road, Ottawa Hospital-General Campus, Ottawa, Ontario K1H 8L6.

Telephone 613-737-8037, fax 613-737-8895, e-mail lbalfour@ottawahospital.on.ca

Received for publication May 18, 2005. Accepted July 20, 2005
} 
The negative physical effects of smoking are worse for people with chronic medical conditions, including liver disease. In a cross-sectional study of 6095 individuals with HCV, Wang et al (6) found that alcohol abuse and cigarette smoking were both independently associated with elevated alanine aminotransferase (ALT) levels. Tobacco smoking has also been linked to hepatocellular carcinoma (7). Among Japanese patients with chronic liver disease (67\% were HCV-positive), the RR of developing hepatocellular carcinoma was 15.4 for those who smoked, even if they did not drink alcohol (8). In a recent study by Hezode et al (9), smoking was associated with increased histological activity in chronic HCV patients independent of alcohol use. These findings justify clinical efforts toward more systematically assessing the impact of smoking on those living with chronic liver disease.

Depressive symptoms are frequently identified in HCV patients (10). Depression occurs in patients who are HCV treatment-naive (11) as well as in patients who have initiated interferon-based therapies (12). The etiology of depression among HCV-infected patients is not completely understood. However, depressive symptoms are consistently related to a compromised health-related quality of life among $\mathrm{HCV}$ patients (11). Whether it is the presence of depressive symptoms that cause decrements in HCV health-related quality of life or vice versa has yet to be established. Depression and reductions in health-related quality of life in HCV infection may also be mediated by behavioural factors. Very high rates of smoking (eg, 48\%) have been consistently reported in depressed populations $(13,14)$. As well, among patients with chronic illnesses, such as cancer and diabetes, alcohol intake, smoking and depression often co-occur $(7,8,15,16)$.

The inter-relationship among health-related quality of life, cigarette smoking and depression is not well described among Canadians living with HCV. In an effort to further elucidate this, patients attending their first evaluation at the Ottawa Hospital General Campus Viral Hepatitis Clinic (Ottawa, Ontario) were asked to complete a comprehensive psychological questionnaire designed to measure health-related quality of life, depression and health behaviours (eg, cigarette smoking and substance use). The objectives of the present study were to compare standardized health-related quality of life scores between Canadian HCV patients and age-matched Canadian and American norms; and to examine the relative association between biopsychosocial factors (ie, age, cigarette smoking and depression) and health-related quality of life among Canadian HCV patients.

\section{METHODS}

All English- or French-speaking HCV patients attending their initial clinic visit at the Ottawa Hospital (General Campus) Viral Hepatitis Clinic between June 2000 and September 2002 were approached to participate in the study. Eligible patients were HCV RNA-positive and not receiving interferon-based HCV drug therapy. The initial clinic visit consisted of a consultation with the HCV nurse and physician, a complete medical assessment, bloodwork and basic education about HCV. The research nurse administered the questionnaire to patients before they received any clinical evaluation, viral hepatitis literature or counselling. All patients provided informed consent before participation as per Ottawa Hospital Research Ethics Board guidelines.

The short form of the health survey-36 (SF-36) (17) was used to measure health-related quality of life. It was chosen because it is the most widely used psychometrically valid and reliable healthrelated quality of life measure among patients with chronic illnesses, such as HCV, HIV, hypertension and diabetes. The SF-36 includes four physical subscales (physical functioning, role limitations due to physical problems, vitality and bodily pain) and four mental subscales (general health perceptions, social functioning, role limitations due to emotional problems and general mental health) (18). Higher scores on SF-36 subscales indicate higher healthrelated quality of life. Coefficient alpha was used to assess the internal consistency of the SF-36 subscales in this cohort.

Depression was assessed using the validated Center for Epidemiologic Studies Depression scale (CES-D) $(19,20)$. This 20-item, self-report scale yields a total score ranging from 0 to 60 , with greater scores indicating a greater degree of depressive symptomatology. The clinical cut-off score for the CES-D is 16; scores equal to or greater than 16 denote a clinical level of depressive symptoms. Internal consistency of the CES-D in this cohort was evaluated using coefficient alpha. Participants were also asked about their past and current health behaviours (eg, cigarette smoking and alcohol use) and risk factors for HCV transmission (eg, drug use and needle sharing).

Student's $t$ tests were used to compare the mean SF-36 subscale scores of Canadian HCV patients with age-matched Canadian norms (18) and American adult population norms (21). The sample was subdivided into smokers and nonsmokers. Health-related quality of life scores of HCV smokers and HCV nonsmokers were compared using Student's $t$ tests. The results of these two groups were then compared with Canadian normative data in a similar manner. To assess the combined impact of smoking and depression on HCV patients' health-related quality of life, the sample was further subdivided by level of depression and smoking status. Patients were classified as depressed or nondepressed using the CES-D clinical cut-off score of 16; those with scores equal to or greater than 16 were classified as depressed whereas those with scores less than 16 were classified as nondepressed (19).

A series of hierarchical multiple regression analyses was performed using the vitality, bodily pain and physical functioning subscales of the SF-36 as the dependent variables. These three subscales were specifically chosen because fatigue (ie, low vitality), bodily pain and poor physical health are symptoms frequently reported by HCV patients (11). The eight independent variables in each hierarchical multiple regression analysis were entered in a series of blocks to ascertain whether each subsequent variable was related to health-related quality of life above and beyond the preceding variables. In the first eight blocks, the independent variables were entered as follows: age; sex; education level; ALT serum level; history of injection drug use; current alcohol use; smoking status; and depression. This allowed for a specific examination of the unique relative contribution of smoking status and depression to patients' health-related quality of life scores after controlling for sociodemographic variables, ALT serum level and health behaviours. Standardized regression coefficients were calculated, which allowed a direct comparison of the relative contribution of each independent variable with the three SF-36 subscales. Statistical significance was set at $\mathrm{P}<0.05$ for all univariate and multivariate analyses.

\section{RESULTS}

Of the 150 patients meeting eligibility criteria, 123 (82\%) agreed to participate in the study (Table 1). Reasons for nonparticipation included lack of time or lack of interest. The 123 patients ( $71 \%$ men; 29\% women) ranged from 20 to 
TABLE 1

Sociodemographic characteristics of 123 Canadian hepatitis $\mathrm{C}$ virus patients

\begin{tabular}{|c|c|}
\hline Characteristic & Patients*, n (\%) \\
\hline Mean age in years $\pm S D$ & $43 \pm 8$ \\
\hline Female sex & $35(28.5)$ \\
\hline HIV coinfection & $12(9.8)$ \\
\hline Past injection drug use & $74(60.2)$ \\
\hline Current cigarette smoker & $78(63.4)$ \\
\hline Depression (CES-D) & $76(61.8)$ \\
\hline \multicolumn{2}{|l|}{ Ethnicity } \\
\hline Caucasian & $112(91.1)$ \\
\hline African & $4(3.3)$ \\
\hline Hispanic & $1(0.8)$ \\
\hline Asian & $3(2.4)$ \\
\hline Other & $3(2.4)$ \\
\hline Mean ALT serum level $( \pm S D), I U / L^{\dagger}$ & $96 \pm 75$ \\
\hline Normal $(<40)$ & $18(15)$ \\
\hline Elevated $(\geq 40)$ & $104(85)$ \\
\hline \multicolumn{2}{|c|}{ Stage of liver disease (METAVIR scoring system) $(n=61)$} \\
\hline Stage $0-2$ & $51(83.6)$ \\
\hline Stage 3-4 & $10(16.4)$ \\
\hline No biopsy performed & $62(50.4)$ \\
\hline Current alcohol use $\mathrm{e}^{\ddagger}$ & $61(49.6)$ \\
\hline \multicolumn{2}{|l|}{ Quantity of current alcohol use $\S$} \\
\hline One to two drinks per occasion & $31(50.8)$ \\
\hline Three or more drinks per occasion & $30(49.2)$ \\
\hline \multicolumn{2}{|l|}{ Relationship status } \\
\hline Single & $50(40.7)$ \\
\hline Divorced & $14(11.4)$ \\
\hline Married/partner & $57(46.3)$ \\
\hline Widowed & $2(1.6)$ \\
\hline \multicolumn{2}{|l|}{ Employment status $\pi$} \\
\hline Full-time & $38(31.4)$ \\
\hline Part-time & $12(9.9)$ \\
\hline Disability & $44(36.4)$ \\
\hline Unemployed & $18(14.9)$ \\
\hline Student & $7(5.8)$ \\
\hline Retired & $2(1.7)$ \\
\hline \multicolumn{2}{|l|}{ Education level completed } \\
\hline Elementary & $10(8.1)$ \\
\hline High school & $65(52.8)$ \\
\hline College & $21(17.1)$ \\
\hline University & $27(22.0)$ \\
\hline
\end{tabular}

*Unless stated otherwise; ${ }^{\dagger}$ Data are missing for one participant; ${ }^{\sharp}$ Based on alcohol consumption over the past 30 days; $\S_{B}$ Based on the average number of drinks consumed per sitting over the past 30 days. Data are missing for six participants; " DData are missing for two participants. ALT Alanine aminotransferase; CES-D Center for Epidemiologic Studies Depression scale

67 years of age (mean 43 years of age). Ninety-one per cent were Caucasian, 39\% had attended university or college and over one-half of patients $(51.3 \%)$ were currently on disability or unemployed. The mean serum ALT level was $96 \mathrm{IU} / \mathrm{L}$. Most patients had minimal fibrosis on biopsy. No patient had clinical liver decompensation, hepatocellular carcinoma or was a liver transplant recipient. No patient was receiving interferonbased HCV drug therapy. Sixty per cent of patients had a
TABLE 2

Comparison of Canadian hepatitis $\mathrm{C}$ virus (HCV) patient health survey short form (SF)-36 subscale scores with age-matched Canadian and American adult population norms*

\begin{tabular}{|c|c|c|c|}
\hline & $\begin{array}{c}\text { Canadian } \\
\text { HCV sample } \\
(n=123)\end{array}$ & $\begin{array}{c}\text { Age-matched } \\
\text { Canadian norms } \\
(n=499)\end{array}$ & $\begin{array}{c}\text { American adult } \\
\text { population norms } \\
(n=2474)\end{array}$ \\
\hline Physical functioning & $67.8(28.4)$ & $90.9(15.1)$ & $84.2(23.3)$ \\
\hline $\begin{array}{l}\text { Role limitations due to } \\
\text { physical problems }\end{array}$ & $48.2(43.7)$ & $83.4(31.6)$ & $80.9(34.0)$ \\
\hline Vitality & $47.0(24.9)$ & $66.1(17.4)$ & $60.9(20.9)$ \\
\hline Bodily pain & $59.2(31.0)$ & $76.2(22.1)$ & $75.2(23.7)$ \\
\hline $\begin{array}{l}\text { Physical component } \\
\text { scale }\end{array}$ & $39.5(12.2)$ & $52.0(8.0)$ & $50.0(10.0)$ \\
\hline General health & $53.0(26.2)$ & $78.9(16.9)$ & $71.9(20.3)$ \\
\hline $\begin{array}{l}\text { Role limitations due to } \\
\text { emotional problems }\end{array}$ & $53.2(44.9)$ & $83.2(32.5)$ & $81.3(33.0)$ \\
\hline Social functioning & $59.3(28.6)$ & $85.5(18.4)$ & $83.3(22.7)$ \\
\hline Mental health & $62.2(21.1)$ & $77.3(14.7)$ & $74.7(18.1)$ \\
\hline $\begin{array}{l}\text { Mental component } \\
\text { scale }\end{array}$ & $40.3(12.1)$ & $50.9(9.0)$ & $50.0(10.0)$ \\
\hline
\end{tabular}

Data are presented as mean (SD). ${ }^{*}$ Canadian $\mathrm{HCV}$ patients scored significantly below age-matched Canadian norms on all SF-36 subscales at $P<0.001$; ${ }^{+}$Canadian HCV patients scored significantly below American adult population norms on all SF-36 subscales at $P<0.001$

history of injection drug use and one-half of the sample reported current alcohol consumption. Cigarette smoking was reported by $63 \%$ of patients. Depression, as defined by a CES-D depression score of 16 or greater, was identified in $62 \%$ of patients.

Ten per cent of the sample was coinfected with HIV, which is representative of the patient population routinely seen at the Ottawa Hospital Viral Hepatitis Clinic. To assess the potentially confounding effect of HIV coinfection, the 12 HIV-HCV coinfected patients were compared with the HCV monoinfected patients $(\mathrm{n}=111)$ using Student's $t$ tests and $\chi^{2}$ analysis. Because no significant differences were identified between these groups in health-related quality of life, depression, smoking status, ALT level or any other sociodemographic variable, all patients were pooled together and included in subsequent analyses.

In the current cohort, coefficient alphas for the SF-36 subscales and the CES-D ranged between 0.75 and 0.93 , demonstrating a high level of internal consistency. Canadian HCV patients scored significantly below age-matched Canadian normative data (18) and American adult population norms (21) on all eight SF-36 subscales $(\mathrm{P}<0.001$ for each measure), indicating that they had significantly compromised health-related quality of life (Table 2). To specifically assess the impact of smoking on health-related quality of life, smokers $(n=78)$ and nonsmokers $(n=45)$ were compared. Smokers were found to have lower scores for general health $(\mathrm{P}<0.05)$, mental health $(\mathrm{P}<0.05)$, vitality (ie, fatigue) $(\mathrm{P}<0.01)$ and bodily pain $(\mathrm{P}<0.01)$ than nonsmokers. Compared with Canadian normative data, results from both HCV smokers and HCV nonsmokers showed significantly reduced health-related quality of life in seven of eight subscales $(\mathrm{P}<0.05$ for each measure). HCV nonsmokers did not differ significantly from Canadian norms on bodily pain $(\mathrm{P}=0.12)$. 


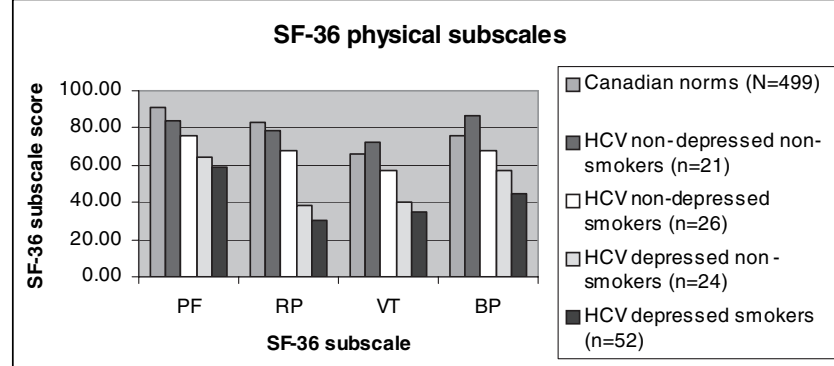

SF-36 mental subscales

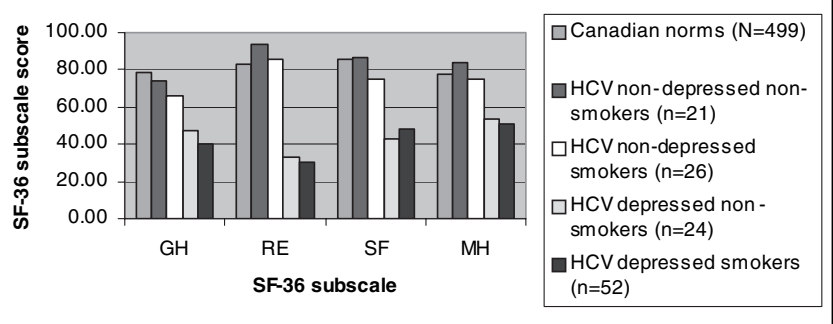

Figure 1) Mean health survey (short form)-36 (SF-36) physical and mental subscale scores of Canadian hepatitis $\mathrm{C}$ virus (HCV) patients grouped by level of depression and smoking status in comparison with age-matched Canadian norms. BP Bodily pain; GH General health perceptions; MH Mental health; PF Physical functioning; RE Role limitations due to emotional problems; RP Role limitations due to physical problems; SF Short form; VT Vitality

The sample was subdivided into four independent HCV groups: depressed smokers $(\mathrm{n}=52)$; depressed nonsmokers $(\mathrm{n}=24)$; nondepressed smokers $(\mathrm{n}=26)$; and nondepressed nonsmokers ( $\mathrm{n}=21$ ) (Figure 1). Results indicated that both HCV depressed smokers $(\mathrm{n}=52)$ and HCV depressed nonsmokers $(n=24)$ had significantly reduced health-related quality of life on all SF-36 subscales in comparison with Canadian norms $(\mathrm{P}<0.001$ for each measure). HCV nondepressed smokers $(n=26)$ had significantly lower health-related quality of life scores in terms of physical functioning $(\mathrm{P}<0.001)$, role limitations due to physical problems $(\mathrm{P}<0.05)$, vitality (ie, fatigue) $(\mathrm{P}<0.05)$, general health $(\mathrm{P}<0.001)$ and social functioning $(\mathrm{P}<0.01)$ in comparison with Canadian normative data. HCV nondepressed smokers $(\mathrm{n}=26)$ differed from Canadian norms for bodily pain, role limitations due to emotional problems and mental health subscales. For most measures, HCV nondepressed nonsmokers $(\mathrm{n}=21)$ had similar health-related quality of life scores to Canadian norms. An exception was the physical functioning subscale on which HCV nondepressed nonsmokers scored significantly lower $(\mathrm{P}<0.05)$. Of note, HCV nondepressed nonsmokers scored at least as well as Canadian normative data on bodily pain and mental health.

A hierarchical multiple regression model consisting of eight key independent variables explained $47 \%$ of the variance associated with vitality (Table 3$)$. Cigarette smoking $(\mathrm{P}=0.044)$ and depression $(\mathrm{P}<0.001)$ were both independently correlated with vitality. A similar pattern emerged for bodily pain. The eight independent variables collectively accounted for $35 \%$ of variance in bodily pain, with cigarette smoking status
TABLE 3

Hierarchical multiple regressions predicting the vitality, bodily pain and physical functioning subscales of the health survey short form (SF)-36 (n=123)

\begin{tabular}{llcc}
\hline Step & Variable & $\begin{array}{c}\text { Standardized } \\
\text { coefficient }(\boldsymbol{b})^{\star}\end{array}$ & $\mathbf{P}$ \\
\hline With the vitality subscale as the dependent variable & \\
1 & Age & 0.16 & 0.076 \\
2 & Sex & -0.16 & 0.076 \\
3 & Education level & 0.08 & 0.391 \\
4 & ALT serum level & -0.06 & 0.530 \\
5 & Past injection drug use & -0.02 & 0.838 \\
6 & Current alcohol use & 0.06 & 0.519 \\
7 & Smoking status & 0.21 & 0.044 \\
8 & Depression & -0.66 & $<0.001$ \\
With the & bodily pain subscale as the dependent variable & \\
1 & Age & 0.06 & 0.489 \\
2 & Sex & -0.15 & 0.102 \\
3 & Education level & 0.04 & 0.654 \\
4 & ALT serum level & 0.04 & 0.694 \\
5 & Past injection drug use & 0.06 & 0.493 \\
6 & Current alcohol use & 0.12 & 0.176 \\
7 & Smoking status & 0.26 & 0.012 \\
8 & Depression & -0.54 & $<0.001$ \\
With the physical functioning subscale as the dependent variable§ \\
1 & Age & -0.20 & 0.028 \\
2 & Sex & -0.13 & 0.164 \\
3 & Education level & 0.13 & 0.171 \\
4 & ALT serum level & 0.02 & 0.805 \\
5 & Past injection drug use & -0.12 & 0.188 \\
6 & Current alcohol use & 0.12 & 0.187 \\
7 & Smoking status & 0.18 & 0.072 \\
8 & Depression & -0.46 & $<.001$ \\
\hline
\end{tabular}

*The standardized regression coefficient (b) shows the direction (positive or negative) and the magnitude of the relationship between each independent variable and the dependent variable: ${ }^{t} R^{2}=47 \%$ for the entire model $(P<0.001) ; \ddagger R^{2}=35 \%$ for the entire model $(P<0.001) ;{ }^{2}=30 \%$ for the entire model $(P<0.001)$. ALT Alanine aminotransferase

$(\mathrm{P}<0.012)$ and depression $(\mathrm{P}<0.001)$ emerging as significantly related to bodily pain. All eight variables in combination accounted for $30 \%$ of variance in physical functioning. Age $(\mathrm{P}<0.028)$ and depression $(\mathrm{P}<0.001)$ were independently correlated with physical functioning.

\section{DISCUSSION}

Mood, illness severity and health behaviours affect healthrelated quality of life in many medical disorders (22-24). In the case of HCV infection, the inter-relationships among these biopsychosocial variables are not fully understood. The results of the present study demonstrate that Canadian HCV patients have significantly lower health-related quality of life scores across physical and mental domains compared with agematched Canadian norms. These results are consistent with those of Chong et al (1). Furthermore, smoking and depression are independently associated with diminished health-related quality of life in this population of HCV patients.

The rate of cigarette smoking (63\%) reported in this HCV infected cohort was much higher than the Canadian national average rate of $24 \%$ at the time of data collection (25). Few 
studies have explored cigarette smoking rates in HCV patients, but among those, very similar high rates of smoking behaviour have been reported among HCV patients in Germany, Australia, France and Taiwan (26-29). In the present study, cigarette smoking was associated with significant decrements in mental and physical health-related quality of life in those chronically infected with HCV. Given that cigarette smoking is a modifiable health behaviour, these findings may have important clinical implications. Smoking cessation interventions may help improve health-related quality of life for those with HCV infection (30). Further study of the effectiveness of psychological and/or pharmacological treatments for smoking cessation and relapse prevention, and the impact of these interventions on HCV patients' long-term health-related quality of life are needed. The present study focused on tobacco cigarette smoking. The tar in marijuana contains similar carcinogens to those found in tobacco cigarettes, and marijuana smoking has been associated with increased risk of head and neck cancer (31). Future research on smoking and HCV health-related quality of life should address marijuana smoking in addition to past and present tobacco smoking behaviour.

High rates of depression (62\%) were also identified in this cohort and were strongly correlated to diminished healthrelated quality of life. Concerns pertaining to the safety of antidepressants in HCV-infected patients may limit the willingness of patients and physicians to initiate pharmacological therapy for depression. The antidepressant nefazodone was withdrawn from the market based in part on evidence of hepatic injury in patients with pre-existing liver disease (32). On the other hand, an open label study (33) of the serotonin reuptake inhibitor citalopram hydrobromide demonstrated that depression can be safely and effectively treated in HCV seropositive patients. Subjects experienced reduced depression and increased health-related quality of life without worsening liver functioning. Cognitive behavioural therapy and interpersonal psychotherapy may be as effective as psychotropic medication in treating mild to moderate depression (34). Such short-term, time-limited empirically validated psychotherapies may offer a genuine alternative treatment for $\mathrm{HCV}$ patients who have mild to moderate depression (35). Long-term follow-up studies also suggest that psychotherapy, or a combination of psychotherapy and antidepressant medication, is more effective in preventing patient relapse into another depression when compared with treatment with antidepressant medication alone (35).

HCV patients frequently describe a collection of nonspecific symptoms, including fatigue, nausea, anorexia, myalgias, arthralgias, headaches, irritability and neurocognitive deficiencies, which compromises their health-related quality of life $(1,2)$. These significant impairments in health-related quality of life span the entire spectrum of HCV disease, from mild to advanced liver disease (1). These symptoms are often attributed by patients and health care providers as being caused by chronic HCV infection. There are few peer-reviewed data to corroborate this. It is biologically plausible given that other chronic, actively replicating viral infections (ie, HIV, cytomegalovirus and Epstein-Barr virus) often produce diffuse and vague systemic symptoms. It is noteworthy that in this evaluation, HCV patients who were not depressed and who abstained from smoking reported health-related quality of life scores at least as high as Canadian norms. Both depression and smoking should be considered in the HCV-infected population before attributing these nonspecific symptoms directly to HCV. The impairments in health-related quality of life and high rates of depression among HCV patients also have important social and economic implications. In the current HCV sample, $36 \%$ were on work disability and $15 \%$ were unemployed. Impairments in work functioning are common among depressed patients $(36,37)$, and they are also reported among $\mathrm{HCV}$ patients (38). It is encouraging that HCV patients who experience a sustained positive response to combination $\mathrm{HCV}$ therapy report improvements in work functioning and productivity (38).

Several limitations of the present study are acknowledged. Recruited HCV patients were drawn from a tertiary hospitalbased clinic, were mostly noncirrhotic and were not on HCV drug treatment. Results may not generalize to patients with more advanced cirrhotic liver disease or to patients on $\mathrm{HCV}$ drug therapy. The study was cross-sectional in design and lacked longitudinal reassessment of results. Prospective studies assessing how HCV disease progression, health behaviours, depression and health-related quality of life interact and change over time are planned. Depression was assessed by the self-report CES-D questionnaire. Although this self-report instrument correlates highly with clinical depression, researchers may consider using criteria from the Diagnostic and Statistical Manual of Mental Disorders, Fourth Edition-TR (39) and the Structured Clinical Interview for DSM-IV-TR (40) for future studies. The impact of smoking and depression on HCV patients' treatment adherence and success in responding to HCV treatments was not assessed in the present study. The role of cigarette smoking in potentially reducing the benefits of $\mathrm{HCV}$ treatments warrants further investigation. Continued smoking has been shown to negate the improvements in health-related quality of life gained from therapeutic interventions in other medical populations (41). Moreover, cigarette smoking has been correlated with economic difficulties and socioeconomic status $(42,43)$. Accordingly, future research would do well to further examine associations between healthrelated quality of life and smoking by incorporating additional measures of patients' socioeconomic status.

In summary, the present study demonstrated that HCVinfected Canadians experience reduced health-related quality of life compared with Canadian norms. The present study highlights the importance of assessing cigarette smoking and depression in HCV clinical care. There is a clear need to provide more access to clinical services for treating depression, encouraging healthier lifestyle behaviours, and using a biopsychosocial treatment model when looking at strategies to improve healthrelated quality of life among Canadians living with $\mathrm{HCV}$.

\section{REFERENCES}

1. Chong CA, Gulamhussein A, Heathcote EJ, et al. Health-state utilities and quality of life in hepatitis $\mathrm{C}$ patients. Am J Gastroenterol 2003;98:630-8.

2. Forton DM, Thomas HC, Murphy CA, et al. Hepatitis C and cognitive impairment in a cohort of patients with mild liver disease. Hepatology 2002;35:433-9.

3. Cordoba J, Flavia M, Jacas C, et al. Quality of life and cognitive function in hepatitis $\mathrm{C}$ at different stages of liver disease. J Hepatol 2003;39:231-8.

4. Vogt MT, Hanscom B, Lauerman WC, Kang JD. Influence of smoking on the health status of spinal patients: The National Spine Network database. Spine 2002;27:313-9.

5. Olufade AO, Shaw JW, Foster SA, Leischow SJ, Hays RD, Coons SJ. Development of the smoking cessation quality of life questionnaire. Clin Ther 1999;21:2113-30. 
6. Wang CS, Wang ST, Chang TT, Yao WJ, Chou P. Smoking and alanine aminotransferase levels in hepatitis $\mathrm{C}$ virus infection: Implications for prevention of hepatitis $\mathrm{C}$ virus progression. Arch Intern Med 2002;162:811-5.

7. Kuper H, Tzonou A, Kaklamani E, et al. Tobacco smoking, alcohol consumption and their interaction in the causation of hepatocellular carcinoma. Int J Cancer 2000;85:498-502.

8. Mukaiya M, Nishi M, Miyake H, Hirata K. Chronic liver diseases for the risk of hepatocellular carcinoma: A case-control study in Japan. Etiologic association of alcohol consumption, cigarette smoking and the development of chronic liver diseases. Hepatogastroenterology 1998;45:2328-32.

9. Hezode C, Lonjon I, Roudot-Thoraval F, et al. Impact of smoking on histological liver lesions in chronic hepatitis C. Gut 2003;52:126-9.

10. Dieperink E, Willenbring M, Ho SB. Neuropsychiatric symptoms associated with hepatitis $\mathrm{C}$ and interferon alpha: A review. Am J Psychiatry 2000;157:867-76.

11. Dwight MM, Kowdley KV, Russo JE, Ciechanowski PS, Larson AM, Katon WL. Depression, fatigue, and functional disability in patients with chronic hepatitis C. J Psychsom Res 2000;49:311-7.

12. Bonaccorso S, Puzella A, Marino V, et al. Immunotherapy with interferon-alpha in patients affected by chronic hepatitis $\mathrm{C}$ induces an intercorrelated stimulation of the cytokine network and an increase in depressive and anxiety symptoms. Psychiatry Res 2001;105:45-55

13. Daniel M, Cargo MD, Lifshay J, Green LW. Cigarette smoking, mental health and social support: Data from a northwestern First Nation.Can J Public Health 2004;95:45-9.

14. Lasser K, Boyd JW, Woolhandler S, Himmelstein DU, McCormick D, Bor DH. Smoking and mental illness: A population-based prevalence study. JAMA 2000;284:2606-10.

15. Duffy SA, Terrell JE, Valenstein M, Ronis DL, Copeland LA, Connors M. Effect of smoking, alcohol, and depression on the quality of life of head and neck cancer patients. Gen Hosp Psychiatry 2002;24:140-7.

16. Haire-Joshu D, Heady S, Thomas L, Schechtman K, Fisher EB Jr. Depressive symptomatology and smoking among persons with diabetes. Res Nurs Health 1994;17:273-82.

17. Ware JE, Snow KK, Kosisnki M, Gandek B. SF-36 Health Survey: Manual and Interpretation Guide. Boston: The Health Institute, 1993.

18. Hopman WM, Towheed T, Anastassiades T, et al. Canadian normative data for the SF-36 health survey. Canadian Multicentre Osteoporosis Study Research Group. CMAJ 2000;163:265-71.

19. Radloff LS. The CES-D scale: A self-report depression scale for research in the general population. Appl Psychol Meas $1977 ; 1: 385-401$.

20. Schroevers MJ, Sanderman, R, van Sonderen E, Ranchor AV. The evaluation of the Center for Epidemiologic Studies Depression (CES-D) scale: Depressed and Positive Affect in cancer patients and healthy reference subjects. Qual Life Res 2000;9:1015-29.

21. Ware JE Jr. SF-36 health survey update. Spine 2000;25:3130-9.

22. Kennedy SH, Eisfeld BS, Cooke RG. Quality of life: An important dimension in assessing the treatment of depression? J Psychiatry Neurosci 2001;26(Suppl):S23-8

23. Kraus MR, Schafer A, Csef H, Scheurlen M, Faller, H. Emotional state, coping styles, and somatic variables in patients with chronic hepatitis C. Psychosomatics 2000;41:377-84.

24. Halman M. Management of depression and related neuropsychiatric symptoms associated with HIV/AIDS and antiretroviral therapy. Can J Infect Dis 2001;12(Suppl C):9C-19C.
25. Health Canada. Canadian tobacco use monitoring survey (CTUMS): Prevalence 2000-2002. <www.hc-sc.gc.ca/hlvs/pubs/tobac-tabac/ctums-esutc-2000/ar-rpa-2000_e.html> (Version current at January 19, 2006).

26. Hauser W, Zimmer C, Schiedermaier P, Grandt D. Biopsychosocial predictors of health-related quality of life in patients with chronic hepatitis C. Psychosom Med 2004;66:954-8.

27. Pessione F, Ramond MJ, Njapoum C, et al. Cigarette smoking and hepatic lesions in patients with chronic hepatitis C. Hepatology 2001;34:121-5.

28. Sladden TJ, Hickey AR, Dunn TM, Beard JR. Hepatitis C virus infection: Impacts on behaviour and lifestyle. Aust N Z J Public Health 1998;22:509-11.

29. Sun CA, Wu DM, Lin CC, et al. Incidence and cofactors of hepatitis $\mathrm{C}$ virus-related hepatocellular carcinoma: A prospective study of 12,008 men in Taiwan. Am J Epidemiol 2003;157:674-82.

30. Fisher EB Jr, Haire-Joshu D, Morgan GD, Rehberg H, Rost K. Smoking and smoking cessation. Am Rev Respir Dis $1990 ; 142: 702-20$

31. Hashibe M, Ford DE, Zhang ZF. Marijuana smoking and head and neck cancer. J Clin Pharmacol 2002;42(11 Suppl):103S-7S.

32. Carvajal Garcia-Pando A, Garcia del Pozo J, Sanchez AS, Velasco MA, Rueda de Castro AM, Lucena MI. Hepatotoxicity associated with the new antidepressants. J Clin Psychiatry 2002;63:135-7.

33. Gleason OC, Yates WR, Isbell MD, Philipsen MA. An open-label trial of citalopram for major depression in patients with hepatitis $\mathrm{C}$. J Clin Psychiatry 2002;63:194-8.

34. Jarrett RB, Rush AJ. Short-term psychotherapy of depressive disorders: Current status and future directions. Psychiatry 1994:57:115-32.

35. Papakostas GI, Petersen T, Mahal Y, Mischoulon D, Nierenberg AA, Fava M. Quality of life assessments in major depressive disorder: A review of the literature. Gen Hosp Psychiatry 2004;26:13-7.

36. Judd LL, Akiskal HS, Zeller PJ, et al. Psychosocial disability during the long-term course of unipolar major depressive disorder Arch Gen Psychiatry 2000;57:375-80

37. Kruijshaar ME, Hoeymans N, Bijl RV, Spijker J, Essink-Bot ML. Levels of disability in major depression: Findings from the Netherlands mental health survey and incidence study (NEMESIS). J Affect Disord 2003;77:53-64.

38. McHutchison JG, Ware JE Jr, Bayliss MS, et al. The effects of interferon alpha-2b in combination with ribavirin on healthrelated quality of life and work productivity. J Hepatol 2001;34:140-7

39. American Psychiatric Association. Diagnostic and Statistical Manual of Mental Disorders (DSM-IV-TR), 4th edn. Washington: American Psychiatric Publishing, 2000.

40. First MB, Spitzer RL, Gibbon M, Williams JBW. Structured Clinical Interview for DSM-IV-TR Axis I Disorders, Research Version. New York: Biometric Research, New York State Psychiatric Institute, 2002.

41. Taira DA, Seto TB, Ho KK, et al. Impact of smoking on healthrelated quality of life after percutaneous coronary revascularization. Circulation 2000;102:1369-74.

42. Rahkonen O, Laaksonen M, Karvonens. The contribution of lone parent-hood and economic difficulties to smoking. Soc Sci Med 2005;61:211-6

43. Siahpush M, Borland R. Socio-demographic variations in smoking status among Australians aged $>$ or $=18$ : Multivariate results from the 1995 National Health Survey. Aust N Z J Public Health 2001;25:438-42. 


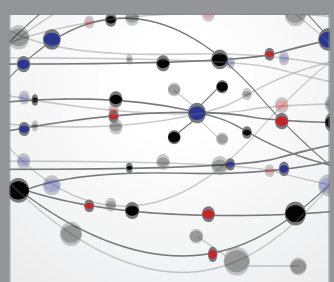

The Scientific World Journal
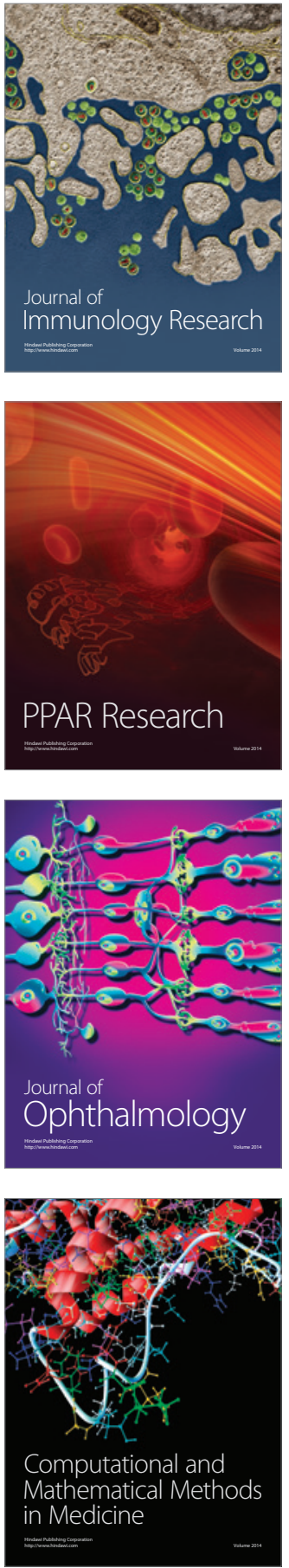

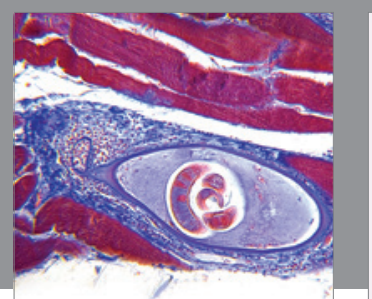

Gastroenterology Research and Practice

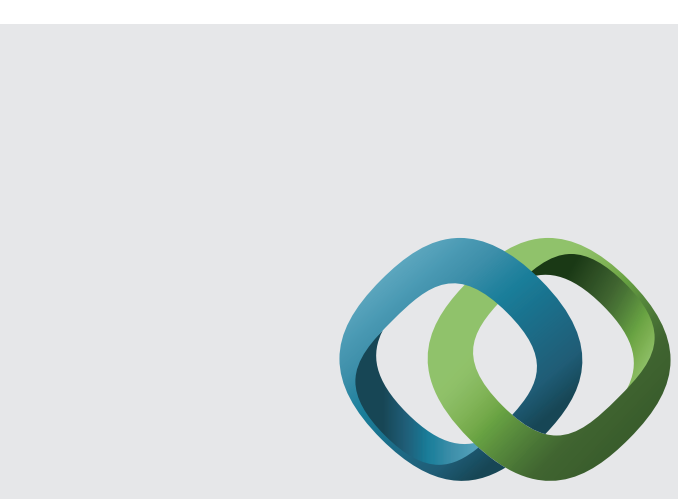

\section{Hindawi}

Submit your manuscripts at

http://www.hindawi.com
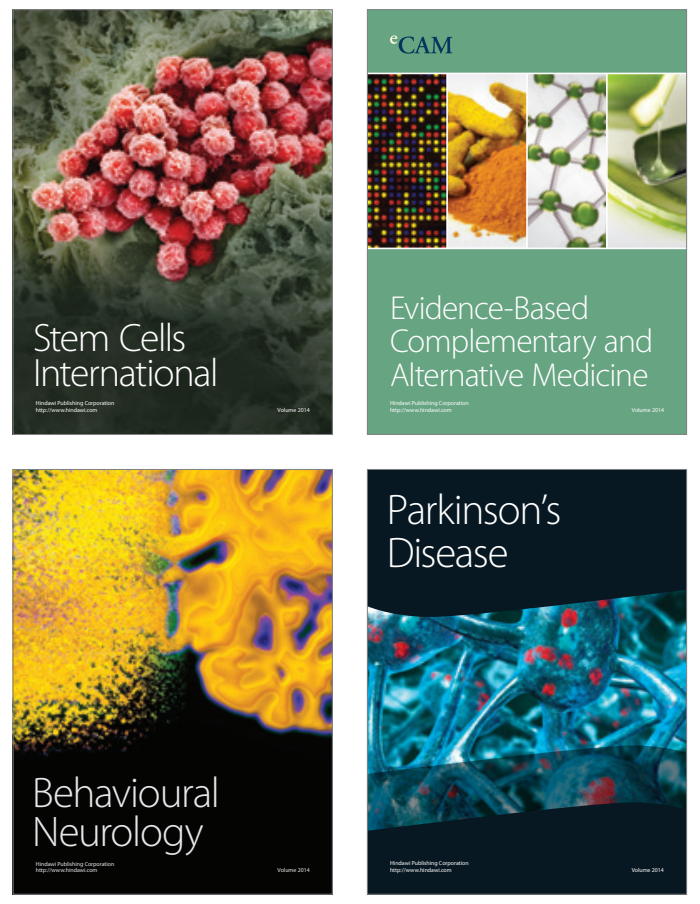
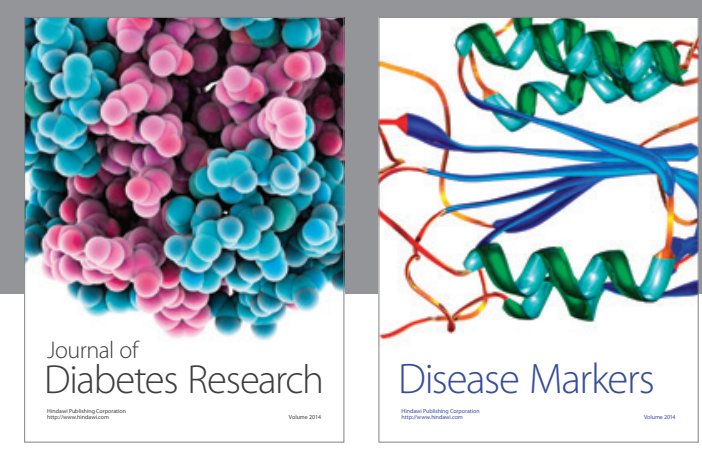

Disease Markers
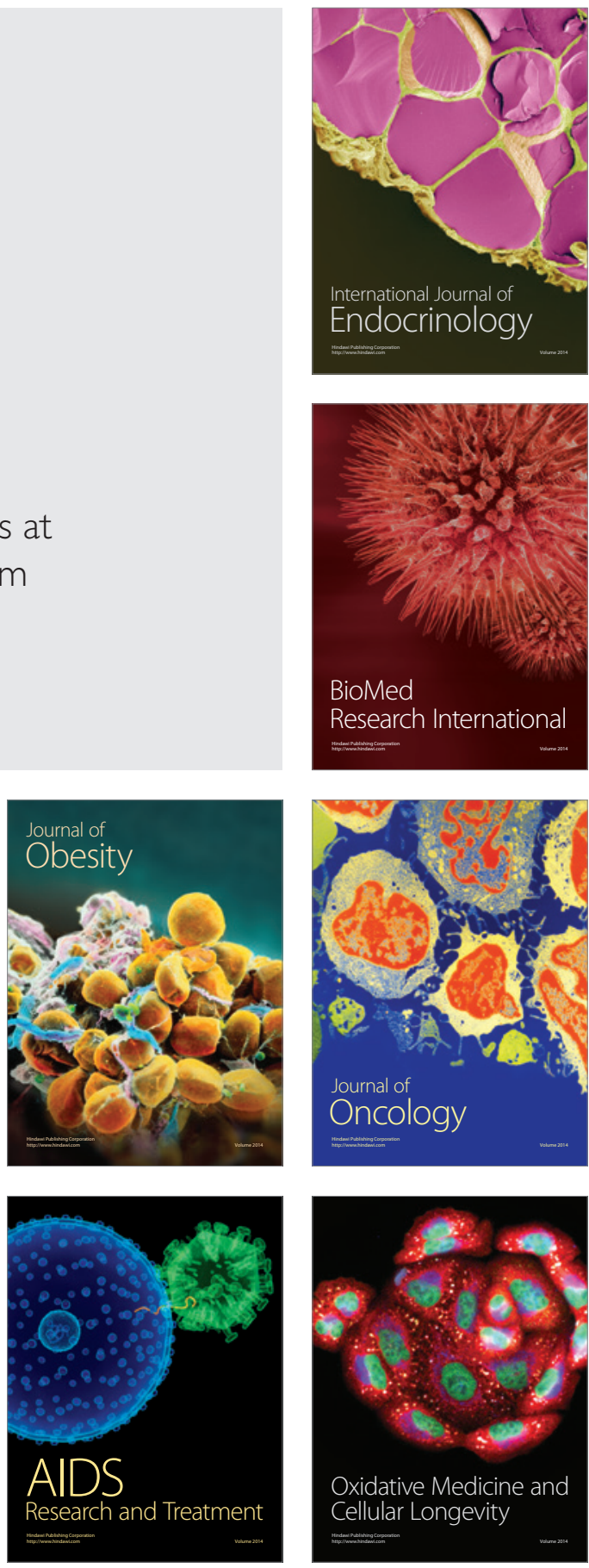